Article

\title{
Locating Religion and Secularity in East Asia Through Global Processes: Early Modern Jesuit Religious Encounters
}

\author{
Jose Casanova \\ Berkley Center for Religion, Peace, and World Affairs, Georgetown University, 3007 M St, NW, Suite 200, \\ Washington, DC 20007, USA; jvc26@georgetown.edu
}

Received: 25 September 2018; Accepted: 23 October 2018; Published: 7 November 2018

\begin{abstract}
The central premise of this paper is that in order to understand the social construction of religion and secularity in East Asia today we need to take a long durée historical approach, which takes into account the colonial encounters between the Christian West and East Asia during three different and distinct phases of globalization. While most of the recent scholarly work on the globalization of the categories of religion and secularity focuses on the second Western hegemonic phase of globalization, this essay focuses on the early modern phase of globalization before Western hegemony.
\end{abstract}

Keywords: globalization; East Asia; Western hegemony; Jesuits; religion; religiosity; secularity

The central premise of this paper is that in order to understand the social construction of religion and secularity in East Asia today we need to take a long durée historical approach, which takes into account the colonial encounters between the Christian West and East Asia during three different and distinct phases of globalization. ${ }^{1}$ The first phase of globalization, before Western hegemony, which in East Asia lasted from the mid-sixteenth-century to the late eighteenth-century, was shaped primarily by the encounters between the Jesuits and other Catholic religious orders and the religions and cultures of East Asia. Although the categories of religion and secularity had not yet acquired a stable and identifiable form during this early modern phase, those early modern colonial encounters, which are the main focus of this paper, played a significant role in the emergence of the categories in the West in the transition from the first to the second phase of globalization.

The second phase of globalization, the phase of Western hegemony proper, lasted roughly from the end of the 18th century to the 1960s. It was during this phase that the categories of religion and secularity entered East Asian discourses, in and through the formation of secular nation states, contributing in the process to the reorganization of the pre-existing religious field in different directions.

Starting from the 1960s, we can distinguish a third phase of globalization, which initiates what we can now recognize as our contemporary global age, after Western hegemony. From the perspective of this paper, significant for this phase is the fact that the categories of religion and secularity have been subject to all kinds of critical, reflexive, post-colonial deconstruction and that the religious field in East Asia is being transformed by newly emerging global dynamics, now affecting simultaneously the entire globe.

1 This essay is based on the Keynote Address delivered at the Inaugural Conference of East Asian Society for the Scientific Study of Religion, removed for peer-review. The text builds upon, at times literally, an earlier elaboration of the argument in Casanova (2018a). 
I use the expression "religious field" to characterize the broader construct within which "religion" and "secularity" are dynamically and interactively situated. Following Van der Veer (2014), one can best understand the "modern" religious field as a structural field of syntagmatic relations of which the main "modern" linguistic expressions are religion and secularity, but also magic (i.e., superstition) and spirituality. Each of these categories must be understood in relation to the others. Their interrelation determines the religious field in any particular context.

In organizing the religious field and in locating religion and secularity within it, diverse groups of agents play a determining role. First and most important has been usually the role of the state and political authorities. Equally significant, most of the time, is the role of competing religious authorities, religious virtuosi, and ordinary religious actors, collective as well as individual. Finally, academic experts and scholars of religion like us have also contributed to the organization of the religious field in manifold ways. But we scholars need to recognize that we are relative latecomers in our attempts to organize scientifically a field which has already been pre-organized for centuries by other agents.

Methodologically, this demands reflexive humility, on our part, to recognize that despite our high-sounding "scientific" claims, the religious field is not something which is objectively out there in nature, waiting for our scientific classifications, definitions, and general theories to replace the pre-existing classifications.

Rather, our task should be to understand and explain how the religious field is being socially constructed constantly by all the competing agents: states, political authorities, and courts; religious authorities, clerics, virtuosi, and religious people; and all the external observers and reporters like ourselves, who in the process also contribute to the continuous social reconstruction of the highly contested religious field.

\section{Religiosity and Secularity}

After several decades of critical deconstruction, we know that both religion and secularity are "modern" "secular" "Western Christian" categories, which have become globalized and now serve to classify and organize differently the religious field all over the globe (Asad 1993, 2003; Beyer 2006; Casanova 2008, 2011, 2012, 2018b; Mazusawa 2005; Nongbri 2013; De Vries 2008). Before becoming "modern" secular analytic categories, they had first emerged with St. Augustin as "Western Christian" theological categories that served to organize the religious field of Western Christendom and the subsequent historical process of European secularization (Casanova 2014).

Both categories, religion and secularity, have become globalized in and through global colonial encounters, beginning with the "first globalization" in the sixteenth-century. In the process, they led to the restructuration of already pre-existing very different religious fields in all non-Western cultures and civilizations. This paper is going to focus on the first phase of globalization with some brief concluding remarks on the second and third phases of globalization.

\section{East Asia}

Well before the first globalization, East Asia already constituted a pre-existing geographic and cultural civilizational region with its own characteristic religious field. The East Asian religious field was first shaped by the penetration of Mahayana Buddhism since the first century AD (Zürcher [1959] 2007). It was later consolidated by the diffusion of state Confucianism from the Middle Kingdom in its Neo-Confucian form, beginning in the twelfth-thirteenth centuries and peaking in the fifteenth-sixteenth centuries across East Asia (de Bary 1989; Liu 1973). As a result, East Asia shared the dynamic integration of the three teachings of Confucianism, Buddhism and Taoism as sanjiao.

In this respect, from a global comparative perspective, East Asia constitutes an ideal comparative unit of research, internally because of its combination of significant similarities and differences, and externally because of its radical differences with the West. At the same time, during the modern era, the entire region was transformed radically, yet very differently, through its diverse encounters with 
Western colonialism. In any case, examining the East Asian religious field comparatively helps to put into question the supposed universal character of modern Western processes and the historical categories derived from them.

Some of the distinguishing characteristics of the East Asian "religious field" have been:

(1) The presence of "states" much older than any and all Western states, which were first formed in the early modern era as internally competing states within the European Westphalian system and as externally competing states in their global colonial expansion. Paradoxically, one can characterize the Asian states as "quasi-religious" states with "sacred" legitimacy (Lagerwey 2010). But simultaneously, they can also be characterized as "proto-secular" states with the authority to organize the religious field through their power to define "orthodoxy" ("right way" or upright teaching) and "heterodoxy" ("crooked path" or "evil cult").

(2) A non-monopolistic context of fluid competition of multiple religious teachings (Confucianism, Buddhism, Taoism), having to vie for hegemony among themselves and with the different local versions of popular animistic folk "religions" (Shinto in Japan, shamanism in Korea, animism in Vietnam). Each of them could become at any time the state religion, or at least the officially recognized "public" religion, while trying to repress the others, pushing them underground or at least relegating them to the private sphere.

(3) The active presence of "proto-secular" observing scholars, the Confucian literati, who tended to look down upon other religious virtuosi and upon all forms of folk religiosity as "superstition" (i.e., magic). In this respect, Confucian scholars may be said to represent a pre-modern proto-secular form of "spiritual, not religious" identity, while one may also talk of "the secular as sacred" (Fingarette 1972).

This unstable and fluid East Asian religious field was changed dramatically by the arrival of the Jesuits and other Western colonial agents during "the first globalization" (Gunn 2003).

\section{Jesuit Interreligious Encounters in East Asia in the First Globalization}

The Jesuits were missionary proselytizers bringing the new "Teaching of the Lord of Heaven", which they claimed to be "the true religion". As such, they entered in competition with the representatives of East Asian teachings. But the Jesuits were simultaneously new "proto-orientalist" observing scholars from the West, who brought Western knowledge to the East and Eastern knowledge to the West. As such, they were received with enormous curiosity as they engaged in intercultural exchanges and dialogue with East Asian scholars. It was this dual identity as missionaries and scholars that made the Jesuits into pioneer globalizers during the first globalization (Casanova 2016a). It also gave them a competitive advantage over other Catholic religious orders that preceded them in South Asia, South East Asia, and East Asia.

The first organized group in history to think and to act globally were the Jesuits, following Jerome Nadal's injunction "the world is our home" (O'Malley 2013). They arrived in Asia sponsored by the Iberian colonial powers, particularly by the Portuguese Padroado (Aulden 1996; Boxer 1978). On the basis of the theological fiction of universal papal jurisdiction over non-Christian lands and peoples, the 1494 Treaty of Tordesillas drew an imaginary meridian line of demarcation, whereby all the lands newly "discovered" or to be discovered west of the line would belong to the Kingdom of Castile, while all the lands east of the line would belong to the Kingdom of Portugal. Naturally, neither other European powers (France, England or the Dutch Republic) nor non-Christian powers recognized the papal jurisdiction over those lands, much less the exclusive colonial claims of the Iberian empires.

In the Western Hemisphere, in the "New World," the Iberian powers were able not only to colonize the indigenous population, but also to impose their spiritual conquest through enforced Catholic confessionalization (Richard 1966). In the Eastern Hemisphere, by contrast, only in the Philippines and to a lesser extent in the Portuguese colonial enclaves of Goa and Macao could the Iberian colonizers reproduce the Latin American model. This was the era of "gunpowder empires" throughout Asia, and the Iberian powers were not in a position to subjugate any of the Asian empires (Ottoman, Persian, Mughal, or Chinese), nor any of the Kingdoms of East, South, or South East Asia (McNeil 1993). 
In this respect it was an era of globalization and of colonial encounters before Western hegemony. But this in itself makes those encounters particularly relevant as we are entering a new age of globalization after Western hegemony. The Jesuits arrived in Goa, Macao, and Nagasaki on Portuguese ships sponsored by the Padroado. But they went beyond, reaching places in the interior of India, Japan, China, and Vietnam, where neither European merchants nor colonists had access. In the process, they initiated a series of intercultural encounters that transformed both East and West.

Alessandro Valignano arrived in Japan in 1579 and initiated the method of "cultural accommodation" or "inculturation" which was soon extended to other Jesuit missions in Asia (Schütte 1980-1985). His ethnographic observations on Japanese religion, culture, and society, presented in his Sumario de las cosas de Japón (1583) marks the beginning of Western scholarship on Japanese civilization (Valignano 1954; Tamburello et al. 2008). The arrival of Michele Ruggieri and Matteo Ricci in Zhaoquing in 1583 marks equally the beginning of the modern intercultural encounter between China and Europe. Particularly Ricci is recognized as the foundation of modern Western Sinology (D'Elia 1942-1949; Po-chia Hsia 2010; Mungello 1989). The same can be said about the arrival of Roberto de Nobili in 1606 in Madurai and the beginning of Western scholarship on Hinduism, the arrival of Alexandre de Rhodes in Vietnam in 1619 and the beginning of Western scholarship on Vietnamese language, religion, and culture, and the arrival of Ippolito Desideri in Llasa in 1716 and the beginning of Western Tibetan studies (de Nobili 2000; Phan 1998; Pomplun 2010). ${ }^{2}$

But it is important to stress that the Jesuit method of "accommodation" was not a cunning strategy devised by European missionaries. It was a practice that emerged out of the intercultural encounter. In Japan as well as in China, their local friends, the first Christians, taught the Jesuits the need to go "native" and to accommodate the local culture if they wanted to succeed. It was his friend and disciple Chü Ju-k'uei (or Chü T'ai-su) who first convinced Matteo Ricci of the need to abandon the habit of a Buddhist monk which he had adopted at first upon entering China with Michele Ruggieri and to assume instead the habitus of a Mandarin scholar (ju) (Rule 1986).

One may take the 1602 World Map of Matteo Ricci, Kunyu Wanguo Quantu, or "Map of the Ten Thousand Countries of the Earth," both as the first graphic evidence of global East Asia and as graphic illustration of the intercultural exchange initiated by the Jesuit mission (Standaert 2002). It was the first modern Chinese World Map with new Chinese names for many of the countries and cities in Europe, Africa, and the New World. It was an intercultural synthesis of Chinese and Western cartography jointly crafted by Matteo Ricci and the Chinese scholars Li Zhizao and Zhang Wentao. It was a synthesis, moreover, that decentered both Europe and the Middle Kingdom by flipping East and West and thus deconstructing both Eurocentrism and Sinocentrism. ${ }^{3}$ In the revised form of the 1674 Kunyu Quantu or "Map of the Whole World", devised by the Belgian Ferdinand Verbiest, another Jesuit cartographer and astronomer in Beijing, it served for two hundred years as the basic global map used in China, Korea, Japan, and Vietnam. ${ }^{4}$

The Jesuit method of cultural accommodation was, moreover, grounded on a deeper theological reflection. They not only realized that they could never succeed in Europeanizing the Japanese or the Chinese, given the latter's own self-esteem and their perception of European culture as "barbarian". The Jesuits also became convinced that in order to take roots in Japan, Christianity itself would have to become Japanese, in the same way as Christianity that was originally Hebrew, had to become truly Greek and Latin. If primitive Christianity could undergo such a fundamental translation and accommodation to Greek and to Roman culture, there was no reason why it could not become also Japanese, Chinese, etc. (Ücerler 2016).

2 More than two thirds of the names on Urs App's list of early modern European orientalists before the establishment of Orientalism in European universities are Jesuits (App 2010). This was, however, Orientalism before the European colonization of Asia and in this respect significantly different from Edward Said (1978). 
The introduction of Christianity in each of the East Asian countries added a new and radically novel form of "religion," which served to de-stabilize an already fluid and pluralistic religious field. It brought new realignments and competitions but also eventually the slow emergence of the modern categories of "religion" and "secular," preparing the way for the emergence of the modern system of "world religions" in the second phase of Western hegemonic globalization.

\section{The Christian Century in Japan}

There are different and contrasting ways of interpreting the relevance of what has been called "the Christian Century in Japan" (Boxer 1951; Ücerler 2008). The high number of Japanese Christians, which are estimated anywhere from 300,000 to 1,000,000, from all walks of life from the highest daimyos to the lowest outcasts, in itself was significant. But more significant was the impact that the encounter with European Catholicism had on Japanese culture and on the determined effort of the Tokugawa regime not only to repress and to exterminate Christianity but to erase any memory of the previous encounter and to construct an authentic Japanese culture purified of any hybrid accretion from the Christian West. Sengoku Japan was undergoing at the time a radical transformation from a feudal "Country at War" to a centralized absolutist state and the Kirishitan played an important catalyst role in this transformation (Casanova 2018a).

From a comparative historical perspective, what is striking about absolutist state formation in Japan is the role played by the ethno-religious cleansing of the Christian minority, by anti-Christian state ideology, and by the confessionalization of the entire Japanese population through the Buddhist and Shinto temple registration system first introduced in 1635 . The state-enforced disciplinary effort continued through the institutionalization of the "Christian aratame" practices through the second half of the 17th century, after Christianity had been wiped out, requiring Japanese to "prove" that they were not Christian. As Kiri Paramore points out, "the establishment of this system represented much more than just an instance of anti-Christian activity: it established an institutionalized system of social control extending to the entire population, a system of control that continued to function until the end of the Tokugawa Shogunate in the late nineteenth century" (Paramore 2009, p. 55).

Later interpretations, by Japanese as well as by Western scholars have taken this Tokugawa Japanese ideology for granted, as an explanation for the ultimate failure of the Jesuits and of Christianity in Japan, as well as a justification for the radical isolationist policies of Sakoku Japan introduced by the Tokugawa, as the need to protect Japan not only from a foreign and un-Japanese religion, but from Western colonialism. Catholic Christianity was rejected naturally as a dangerous foreign body which, besides being an inferior and questionable form of Christianity, was essentially "other" and, therefore, ultimately unassimilable without undermining Japanese culture and Japanese identity (Elison 1973).

Japan represents the first non-European absolutist, secular state which developed not in imitation to the West, or consciously following the principles of Hobbes' Leviathan, yet following a pattern similar and parallel to the European confessional states. The Tokugawa state itself was non-confessional, and in this respect it could be characterized as "secular". Yet it introduced a policy of confessionalization of its population by enforcing the registration of every Japanese subject in Buddhist or Shinto temples, akin to the European parish registration system. Again, what was important was not that everybody had to become Buddhist, but that everybody had to become Japanese, as defined by the state. The aim of the anti-Christian state crusade was not the establishment of Buddhist "religion" per se, but the Japanization of the population. Buddhism was only a national instrument of Japanization. After the Meiji restoration, the Japanese state easily switched from Buddhism to nationalist Shintō in order to enforce an even more rigid policy of Japanization, while renewing its anti-Christian ideology (Paramore 2009).

\section{Jesuit Project in Imperial Neo-Confucian China}

China represented a very different type of colonial encounter. China was a huge empire, stable and relatively pacified, governed by a civil imperial bureaucracy of cultured literati. Yet, the Jesuit 
method of accommodation was also introduced with relative success first under the Ming dynasty and later continued under the Qing dynasty. The ultimate goal of Ricci and the Jesuits who followed him was to penetrate the imperial court of Beijing and to convert the Chinese emperor. The Constantinian model of imperial conversion from above was indeed taken for granted by European Catholics.

But Ricci soon realized that he had to become first Chinese before the Chinese could possibly become Christians. It demanded an arduous enterprise of double translation, of translation of Latin texts and of European culture into Chinese and of translation of Chinese texts and Chinese culture into Latin and into European culture. Ricci himself through his own sinicization was the key to this collective enterprise in which European Jesuits as well as Christian Confucian scholars participated. Ricci's translation of Euclid's Elements into Chinese, his Treatise on Friendship introducing famous aphorisms from Greek, Latin, and Christian authors into Chinese, his Catechism T'ien-chu shih-i (True Meaning of the Lord of Heaven), and his World Map "of the myriad nations of the earth" fusing Western and Chinese cartography, are the most famous illustrations of Ricci's contribution to this collective translation enterprise.

The effect of the translation of Chinese classics and culture first into Latin and then into European languages and cultures, mediated primarily by the China Jesuits, was probably even more crucial for European historical developments (Mungello 2013). Ricci and other Jesuits played a crucial role in the "manufacturing" of "Confucius" and Confucianism and in their significant reception in 17th and 18th century Europe (Jensen 1997; Mungello 1977). But it is important to stress that this dual and reciprocal process of inculturation, which crystallized in a novel form of Confucian Christianity or Christian Confucianism, was the result of synthetic collaboration and intercultural dialogue between European Jesuits and Chinese scholars such as Yang T'ing-yün, Li Chih-Tsao, and Hsü Kuang-ch'i, widely known as "the Three Pillars of Christianity in China" (Peterson 1988).

Jacques Gernet (1985) famously argued that those Chinese scholars were not truly "Christian" because they did not know the true European Christianity. Moreover, the whole encounter was based on a fundamental misunderstanding between two supposedly incommensurable cultures and conceptions of "religion." But Gernet's evaluation is based on a post-Enlightment secularist conception of Christian "religion" and on a modern essentialist conception of Western and Chinese civilizations as fixed and radically different totalities.

The encounters of early modernity show precisely that civilizational boundaries were by no means fixed and firm, but they would become so as a result of the very colonial encounters. In retrospect, re-examining the Jesuit encounters, we can certainly assume that the Christian impact on China was probably much less relevant and certainly less lasting than the Chinese impact on Christian Europe (Standaert 2008). ${ }^{5}$ The Jesuit translation and introduction of Chinese culture into the European public sphere, particularly as it was mediated through the Chinese Rites controversy, played a crucial role in shaping what became the Enlightenment critique of religion, and in this respect affected the European process of secularization (Rubiés 2005).

The Jesuit encounter with the complex religious field they found in Asian societies forced them to rethink the classificatory categories of religion they had brought with them. In the process they contributed unintendedly to the modern differentiation of religion and culture and to the pluralist global system of world religions that became institutionalized in the 20th century (Beyer 2006; Mazusawa 2005).

Let me quote from a letter of Matteo Ricci to the Spanish colonial administrator in the Philippines, Juan Bautista Román, in which he tries to make sense of the complex Chinese religious field he has encountered. This is actually Ricci's earliest surviving letter from China, written on 13 September

5 Recently, a more nuanced revisionist account of the long lasting and continuous implantation of indigenous forms of Chinese Christianity has been emerging (Mungello 2012; Standaert 1997). 
1584, almost exactly one year after he and Ruggieri arrived in Zhaoquing from Macao. I am going to translate freely from the Italian-Portuguese-Spanish "creole" frequently used by Jesuits in East Asia. Ricci (1913, pp. 48-49) writes:

Let me say a few words about the religions and sects of China, without being too precise, since there is no religion in China and the small amount of cult that exists is so intricate that even their own religious people cannot give a good account of it. Leaving aside the Moors, which I do not know how they got here, the Chinese are divided into three sects: one is called heguia (Buddhists), the other cilitan (Daoists) and the most celebrated is the one of the literati, who normally do not believe in the immortality of the soul, make fun of the assertions of the other two, and only give thanks to heaven and earth for the benefits they receive, but do not pray for salvation in the afterlife.

I've placed in italics the various references to the different "religious" phenomena to indicate that the terms religion, religions, religious at the time, at the end of the 16th century, were still unstable and did not yet have the precise meanings which they would acquire later towards the end of the 18th century (Smith 1998). The Jesuits at the time throughout their global missions used interchangeably such terms as "faith" (particularly in reference to the Holy Catholic Faith), "religion" (mostly when referring to the true Catholic religion, de vera religione), teachings (to refer to both orthodox Christian doctrines and heterodox ones, such as those of Christian heretics and sectarians, Christian schismatics, the doctrines of Jewish and Muslim infidels, and pagan and idolatrous doctrines), and laws (Jewish, Christian, Muslim, etc.). Cult refers to sacred rituals, not to the modern meaning of a dangerous "cult" that ought to be outlawed for public protection.

The assertion, "there is no religion in China", obviously only means there is no true religion. Religiones in the plural at the time usually referred not to "religions" in the modern sense of the term but to the multiple Catholic religious orders (Benedictines, Franciscans, Dominicans, etc.). Analogically, Ricci is going to refer to the various "religions" or monastic orders or "sects" he has found in China. The reference to "their own religious people" is also to the various orders of religious virtuosi. Besides the Moors, the name given to Muslims at the time in Southern Latin Europe, who Ricci clearly does not view as part of Chinese religion, he identifies the three Chinese teachings (sanjiao), as Buddhists, Daoists, and literati. The literati are not yet identified as Confucians, or followers of the teachings of Kong-fu-zi, the name which Ricci and the Jesuits would use for Kong-zi, the more common Chinese name of the Sage, which they turned into the Latin Confucius (Jensen 1997).

Already in his early encounter with Confucian teachings, Ricci realizes that they do not believe in the immortality of the soul or in salvation in the afterlife, look down upon Buddhist and Daoist teachings as superstition, and practice no idolatrous rituals, other than thanksgiving to heaven and earth. Clearly such teachings do not fit the category of pagan idolatrous religion. Indeed, they seem more like a proto-secular moral teaching, analogous to the moral teachings of ancient Greek and Latin classic authors, such as Socrates, Cicero, and Seneca, which Jesuits had incorporated into the Christian Humanism they were spreading in Jesuit colleges throughout the world through their Ratio Studiorum, the Jesuit liberal arts curriculum (O’Malley 2016; Maryks 2016).

If Cicero could be inducted as a "Saint" in Jesuit colleges, the more so, Ricci was convinced, could Kung-fu-zi be venerated as a "saint." Ricci was soon recognized by his Chinese peers as a scholar of the Chinese classics, provoking both great admiration for his erudition and virtue, but also great animosity for his relentless attacks on Buddhism and his attempt to purify the reigning Neo-Confucianism from the materialism, which Ricci viewed as a later accretion and as deviation from the ancient teachings. Towards the end of his life in a 1609 letter to Francesco Pasio, a fellow Jesuit in the Japan mission, Ricci (1913, p. 385) wrote:

In ancient times they [i.e., Chinese] followed the natural law more faithfully than in our own countries. And 1500 years ago, this people was not inclined to the worship of idols ... On the contrary, the books of the literati, which are the most ancient and authoritative among their writings, do not adore anything but heaven and earth and the Lord of both. And if we examine these books, we will find little therein against the light of reason and much that is in conformity with it $[\ldots]$ and we can 
hope in Divine mercy and that many of their ancient sages were saved by their observance of the natural law with the help that God would have given them on account of their goodness.

Leaving aside the accuracy of Ricci's interpretation of Confucianism and his negative view of Buddhism and Daoism, two things become evident from Ricci's letters. First, in their encounters with the religious other, the Jesuits are confronted with forms of religious pluralism that could not easily be fitted within the traditional taxonomies of "false" pagan or idolatrous religions. Secondly, in their recourse to natural law and the light of reason in order to account for the nature of this religious pluralism, the Jesuits initiate in fact a form of inter-cultural and interreligious encounter that takes place without reference to revelation. In a certain sense, one finds here the seeds of that which Peter Berger (2014) has identified as the two types of "modern" pluralism: multi-religious pluralism and secular-religious pluralism.

Crucial was the distinction that the Jesuits introduced in China between religion and culture; between, on the one hand, universal Christian religion, which per se is non-European, and therefore can become inculturated in any and all particular cultures, and, on the other, those components of the particular religious cultures that are idolatrous, and therefore cannot become Christianized. Those idolatrous components of culture have to be rejected. However, those components of culture that are not idolatrous, that are civil rather than religious, are neutral and therefore can become Christianized. This is the way in which Confucianism, as interpreted by the Jesuits, was understood not as an idolatrous religion, but as a humanist culture, as a natural morality, and as a civil cult. Unintentionally, once the distinction was incorporated into European debates, it signaled the beginning of the breakdown of the monotheistic distinction between "true" and "false" religion on which the entire structure of Christendom had been based (Assmann 2010).

The distinction between religion and culture was at the core of the Chinese Rites controversy (Mungello 1994). Other Catholic missionaries (Dominicans, Franciscans), and the curial officers at the Propaganda Fide rejected the Jesuit interpretation of the Chinese Rites as cultural, civic rites, insisting that they were idolatrous religious rituals that Chinese Christians had to reject. The European philosophes, however, accepted the Jesuit distinction but turned it against them and against Christianity and all revealed theist religions.

Having learned from the Jesuits that Confucianism represented a kind of deist natural religion before revelation, they gladly affirmed those elements of the Chinese rites which the Jesuits interpreted as civic customs, not as religion, to insist that this is what was needed in Europe, a deist natural religion based on civic customs, while rejecting the supernatural theist superstitious rites of revealed Christian religion. Confucian culture was indeed superior to Christian religion. This explains the Chinese craze of the European Enlightenment and deism. European deists could easily recognize the superiority of Chinese Confucian culture over European Christian culture.

John Lagerwey (2010, pp. 2-3) goes so far as to blame the Jesuits for establishing the foundation on which the entire project of secular "modernity" and "modernization" was built in the West, as well as in China. In his view, it was based on "an incomprehensible misunderstanding," fostered by the Jesuits, that has "continued to dominate Western studies of China," namely that China, at least the China of the elite, "had no religion." Lagerwey actually interprets this misunderstanding as "a profound complicity" between Jesuit Thomist rationalism and the neo-Confucian rationalism that had become hegemonic "thanks to the 'ritual revolution' of the sixteenth century."

For Laggerwey, the Jesuits appear to be accomplice in the project of the neo-Confucian elite "to transform Chinese society by ridding it of the rituals of shamans, Buddhists, and Daoists and putting Confucian rituals in their place." But accusing the Jesuits in the rites controversy of taking a "Calvinistic" view of sacramental rites as "merely symbolic" and of adopting a proto-secularist modern attitude seems to be farfetched, indeed an anachronistic misreading of a much more complex early modern attitude before the triumph of the modern "religious/secular" binary classification of reality.

Early modern Jesuits became famous not only as missionaries and court confessors but also as mathematicians, astronomers, map-makers, land-surveyors, and military engineers at the service of 
royal courts throughout Europe and Asia. Clearly, they had learnt not so much to compartmentalize, as Berger (2014) would say, but rather to integrate what to us appear as different religious and secular roles within society and within their minds, even if their ultimate orientation was "ad majorem Dei gloriam," to which they added for "the good of souls" and "the common good." Jesuits were to find "God in all things" and transcendence in the immanent world.

Moreover, their method of "discernment" learnt in the Spiritual Exercises, helped them to be attuned to the world of "the spirit" in the midst of the most profane tasks. It is not surprising that Étienne Pasquier in his Le Catéchisme des Jésuites (1602), one of the first works in a long list of anti-Jesuit treatises that would contribute to the Jesuit Black legend, characterizes them as a hermaphrodite "religious" order actively engaged in worldly "secular" affairs. With his critique, Pasquier was offering one of the first French formulations of the strict separation between the private world of religion and the public world of laïcité.

Historically, with their final defeat in the "rites controversy" at the beginning of the 18th century, the Jesuit accommodating way of proceeding lost the battle within the Church and within the wider world. In retrospect, one may say that the Jesuit early modern imaginary of global humanity and their dia-praxis of cultural "accommodation" and local inculturation appears less Euro-centric, less racist, and less unilinear than later imaginaries associated with the cosmopolitan Enlightenment or with hegemonic Western modernity (Casanova 2016b).

In the 19th century with the triumph of Western colonialism, the European attitude towards China and all oriental civilizations radically changed. Now, the hegemonic military and technological superiority of industrial capitalism and political and economic liberalism proved the superiority of modern Western civilization over traditional Asian cultures and justified the imperial "White Man's Burden" and its mission civilisatrice.

The second phase of Western hegemonic globalization begins in global East Asia with the unequal treaties, unilaterally enforced, all of them demanding free trade, Western colonial access through foreign protectorates or outright colonization as in French Indochina, and freedom of religion for competing Protestant and Catholic missionaries. Indeed, East Asian neologisms (shukyo, zongjiao) for the modern Western secular concept of "religion" were first used in the translation of the unequal treaties and their demand for "freedom of religion." What had been originally a Buddhist term for a "particular sect" was now used to translate "Western religion", i.e., Christianity, and similar private particularist "sects" in juxtaposition to what was perceived as obligatory national "culture." The Meiji restoration, while accommodating the Western colonial demand for freedom of religion insisted that state enforced Shintō was not an established "religion" but Japanese national "culture." The particular way in which the modern categories of "religion" and "secularity" took root in modern Japan have been well studied (Jun'ichi 2014). But similar problems of translation, semantic reconfigurations of religious and secular discourses, and radical transformations of the religious field became a common phenomenon in all projects of modernization across Asian societies (Eggert and Hölscher 2013). The continuing difficulties in the semantic classification of Confucianism within the modern religious/secular binary discourse are also well known (Sun 2013).

The widespread attraction that Marxism-Leninism held as atheist scientific materialism and as an ideology of societal modernization for East Asian intellectuals may be related to some of its elective affinities with Confucian proto-secularity. Once in power, East Asian intellectuals in China, Korea, and Vietnam institutionalized radical versions of state secularism directed against all forms of traditional religion and feudal superstition.

As we are entering our contemporary post-modern, post-secular global age, which may be viewed as a third phase of globalization after Western hegemony, "the religious question" has reemerged throughout East Asia (Goossaert and Palmer 2011). The religious fields in China, Japan, Korea, and Vietnam are being transformed again rapidly and diversely under the influence of new religious global dynamics (Van der Veer 2014, 2015). There is an urgent need to deconstruct and rethink in East Asian vernacular terms the categories of religion, secularity, magic, and spirituality in order to offer a 
better understanding of changing East Asian religious fields. The newly created East Asian Society for the Scientific Study of Religion should be in a privileged position to contribute to this important comparative research task.

Funding: This research received no external funding.

Conflicts of Interest: The author declares no conflicts of interest.

\section{References}

App, Urs. 2010. The Birth of Orientalism. Philadelphia: University of Pennsylvania Press.

Asad, Talal. 1993. Genealogies of Religion. Baltimore: The Johns Hopkins University Press.

Asad, Talal. 2003. Formations of the Secular. Stanford: Stanford University Press.

Assmann, Jan. 2010. The Price of Monotheism. Stanford: Stanford University Press.

Aulden, Dauril. 1996. The Making of an Enterprise: The Society of Jesus in Portugal, Its Empire, and Beyond, 1540-1750. Stanford: Stanford University Press.

Berger, Peter. 2014. The Many Altars of Modernity. Towards a Paradigm for Religion in a Pluralist Age. Boston: De Gruyter.

Beyer, Peter. 2006. Religions in Global Society. New York: Routledge.

Boxer, Charles Ralph. 1951. The Christian Century in Japan, 1549-1650. Berkeley: University of California Press.

Boxer, Charles Ralph. 1978. The Church Militant and Iberian Expansion, 1440-1770. Baltimore: Johns Hopkins University Press.

Casanova, José. 2008. Public Religions Revisited. In Religion. Beyond a Concept. Edited by Hent de Vries. New York: Frodham University Press, pp. 101-19.

Casanova, José. 2011. The Secular, Secularizations, Secularisms. In Rethinking Secularism. Edited by Craig Calhoun, Mark Juergensmeyer and Jonathan Van Antwerpen. New York: Oxford University Press, pp. 54-74.

Casanova, José. 2012. Religion, the Axial Age, and Secular Modernity in Bellah's Theory of Religious Evolution. In The Axial Age and Its Consequences. Edited by Robert N. Bellah and Hans Joas. Cambridge: Harvard University Press, pp. 191-221.

Casanova, José. 2014. The Two Dimensions, Temporal and Spatial, of the Secular: Comparative Reflections on the Nordic Protestant and Southern Catholic Patterns from a Global Perspective. In Secular and Sacred? The Scandinavian Case of Religion in Human Rights, Law and Public Space. Edited by Rosemarie van den Breemer, José Casanova and Trygve Wyller. Göttingen: Vandenhoeck \& Ruprecht, pp. 21-22.

Casanova, José. 2016a. The Jesuits through the Prism of Globalization, Globalization through a Jesuit Prism. In Jesuits and Globalization. Edited by Thomas Banchoff and José Casanova. Washington, DC: Georgetown University Press, pp. 261-85.

Casanova, José. 2016b. Jesuits, Connectivity, and the Uneven Development of Global Consciousness since the Sixteenth Century. In Global Culture: Consciousness and Connectivity. Edited by Roland Robertson and Didem Buhari-Gulmez. Burlington: Ashgate, pp. 109-26.

Casanova, José. 2018a. Asian Catholicism, Interreligious Encounters, and the Dynamics of Secularism in Asia. In The Secular in South, East and Southeast Asia. Edited by Kenneth Dean and Peter van der Veer. New York: Palgrave Macmillan, pp. 13-35.

Casanova, José. 2018b. The Karel Dobbelaere lecture: Divergent Global Roads to Secularization and Religious Pluralism. Social Compass 65: 187-98. [CrossRef]

D'Elia, Pasquale, ed. 1942-1949. Fonti Ricciane. Storia dell'Introduzione del Cristianesimo in Cina. 3 vols. Roma: Libreria dello Stato.

de Bary, William Theodore. 1989. Neo-Confucian Education: The Formative Stage. Berkley: University of California Press. de Nobili, Roberto. 2000. Preaching Wisdom to the Wise: Three Treatises by Roberto de Nobili, S.J., Missionary and Scholar in 17th Century India. Translated by Anand Amalass, and Francis X. Clooney. St. Louis: Institute of Jesuit Sources.

De Vries, Hent, ed. 2008. Religion: Beyond a Concept. New York: Fordham University Press.

Eggert, Marion, and Lucian Hölscher, eds. 2013. Religion and Secularity. Transformations and Transfers of Religious Discourses in Europe and Asia. Leiden: Brill. 
Elison, George. 1973. Deus Destroyed. The Image of Christianity in Early Modern Japan. Cambridge: Harvard University Press.

Fingarette, Herbert. 1972. Confucius. The Secular as Sacred. San Francisco: Harper.

Gernet, Jacques. 1985. China and the Christian Impact: A Conflict of Cultures. Cambridge: Cambridge University Press. Goossaert, Vincent, and David A. Palmer. 2011. The Religious Question in Modern China. Chicago: University of Chicago Press.

Gunn, Geoffrey C. 2003. First Globalization. The Eurasian Exchange, 1500-1800. Lanham: Rowman \& Littlefield.

Jensen, Lionel M. 1997. Manufacturing Confucianism. Chinese Traditions and Universal Civilization.. Durham: Duke University Press.

Jun'ichi, Isomae. 2014. Religious Discourse in Modern Japan. Religion, State, and Shintō. Leiden: Brill.

Lagerwey, John. 2010. China. A Religious State. Hong Kong: Hong Kong University Press.

Liu, James T. C. 1973. How Did a Neo-Confucian School Became State Orthodoxy? Philosophy East and West 23: 483-505. [CrossRef]

Maryks, Robert A. 2016. Saint Cicero and the Jesuits: The Influence of the Liberal Arts on the Adoption of Moral Probabilism. New York: Routledge.

Mazusawa, Tomoko. 2005. The Invention of World Religions. Chucago: University of Chicago Press.

McNeil, William H. 1993. The Age of Gunpowder Empires, 1450-1800. In Islamic and European Expansion: The Forging of a Global Order. Edited by Michael Adas. Philadelphia: Temple University Press, pp. 103-39.

Mungello, David Emil. 1977. Leibniz and Confucianism: The Search for Accord. Honolulu: Hawaii University Press.

Mungello, David Emil. 1989. Curious Land: Jesuit Accommodation and the Origins of Sinology. Honolulu: University of Hawaii Press.

Mungello, David Emil, ed. 1994. The Rites Controversy: Its History and Meaning. Nettetal: Steyler Verlag.

Mungello, David Emil. 2012. Reinterpreting the History of Christianity in China. The Historical Journal 55: 533-52. [CrossRef]

Mungello, David Emil. 2013. The Great Encounter of China and the West, 1500-1800. Lanham: Rowman \& Littlefield.

Nongbri, Brent. 2013. Before Religion. A History of a Modern Concept. New Haven: Yale University Press.

O'Malley, John W. 2013. Saints or Devils Incarnate? Studies in Jesuit History. Leiden: Brill.

O'Malley, John W. 2016. Historical Perspectives on Jesuit Education and Globalization. In The Jesuits and Globalization. Edited by Thomas Banchoff and José Casanova. Washington, DC: Georgetown University Press, pp. 147-66.

Paramore, Kiri. 2009. Ideology and Christianity in Japan. New York: Routledge.

Peterson, Willard J. 1988. Why Did They Become Christians? Yang T'ing-yün, Li Chih-tsao, and Hsü Kuang-ch'I. In East Meets West. The Jesuits in China, 1582-1773. Edited by Charles E. Ronan and Bonnie B. C. Oh. Chicago: Loyola University Press, pp. 129-52.

Phan, Peter C. 1998. Mission and Catechesis: Alexandre de Rhodes and Inculturation in Seventeenth-Century Vietnam. Maryknoll: Orbis Books.

Po-chia Hsia, Ronald. 2010. A Jesuit in the Forbidden City: Matteo Ricci, 1552-1610. Oxford: Oxford University Press. Pomplun, Trent. 2010. A Jesuit on the Roof of the World: Ippolito Desideri's Mission to Tibet. Oxford: Oxford University Press. Ricci, Matteo. 1913. Opere Storiche. Vol II: Lettere dalla Cina. Edited by Pietro Tacchi-Venturi. Macerata: Filippo Giorgetti. Richard, Robert. 1966. The Spiritual Conquest of Mexico: An Essay on the Apostolate and the Evangelizing Methods of the Mendicant Orders in New Spain. Berkeley: University of California Press.

Rubiés, Joan-Pau. 2005. The Concept pf Cultural Dialogue and the Jesuit Method of Accommodation: Between Idolatry and Civilization. Archivum Historicum Societatis Jesu 74: 237-80.

Rule, Paul. 1986. K'ung-tzu or Confucius? The Jesuit Interpretation of Confucianism. Sydney: Allen \& Unwin.

Said, Edward W. 1978. Orientalism. New York: Pantheon Books.

Schütte, Josef Franz. 1980-1985. Valignano's Mission Principles for Japan. 2 vols. St. Louis: Institute of Jesuit Sources.

Smith, Jonathan Z. 1998. Religion, Religions, Religious. In Critical Terms for Religious Studies. Edited by Mark C. Taylor. Chicago: The University of Chicago Press, pp. 269-85.

Standaert, Nicolas S. J. 1997. New trends in the historiography of Christianity in China. Catholic Historical Review 83: 573-613. [CrossRef]

Standaert, Nicolas S. J. 2002. Methodology in View of Contact between Cultures: The China Case in the 17th Century. Hong Kong: The Chinese University of Hong Kong. 
Standaert, Nicolas S. J. 2008. Jesuits in China. In The Cambridge Companion to the Jesuits. Edited by Thomas Worcester. Cambridge: Cambridge University Press, pp. 169-85.

Sun, Anna. 2013. Confucianism as a World Religion: Contested Histories and Contemporary Realities. Princeton: Princeton University Press.

Tamburello, Adolfo, M. Antoni J. Ücerler, and Marisa di Russo, eds. 2008. Alessandro Valignano S.I. Uomo del Rinascimento: Ponte tra Oriente e Occidente. Rome: IHSI.

Ücerler, Murat Antoni John. 2008. The Jesuit enterprise in sixteenth- and seventeenth-century Japan. In The Cambridge Companion to the Jesuits. Edited by Thomas Worcester. Cambridge: Cambridge University Press, pp. $153-68$.

Ücerler, Murat Antoni John. 2016. The Jesuits in East Asia in the Early Modern Age: A New 'Aeropagus' and the 'Re-invention' of Christianity. In Jesuits and Globalization. Edited by Thomas Banchoff and José Casanova. Washington, DC: Georgetown University Press, pp. 27-48.

Valignano, Alessandro. 1954. Sumario de las Cosas de Japón (1583). Tokyo: Sophia University Press.

Van der Veer, Peter. 2014. The Modern Spirit of Asia. The Spiritual and the Secular in China and India. Princeton: Princeton University Press.

Van der Veer, Peter, ed. 2015. Handbook of Religion and the Asian City. Aspiration and Urbanization in the Twentieth-First Century. Berkeley: University of California Press.

Zürcher, Erik. 2007. The Buddhist Conquest of China: The Spread and Adaptation of Buddhism in Early Medieval China, 3rd ed. Leiden: Brill. First published 1959.

(C) 2018 by the author. Licensee MDPI, Basel, Switzerland. This article is an open access article distributed under the terms and conditions of the Creative Commons Attribution (CC BY) license (http://creativecommons.org/licenses/by/4.0/). 